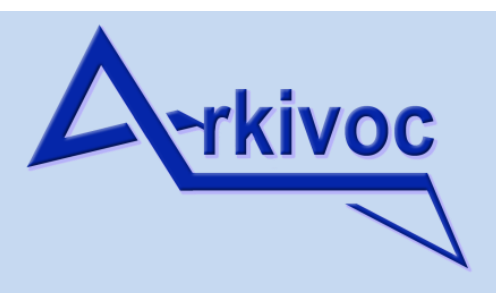

Archive for

Organic Chemistry
The Free Internet Journal

for Organic Chemistry
Paper

Arkivoc 2017, part iv, 34-50

\title{
Novel push-pull thieno[2,3-b]indole-based dyes for efficient dye-sensitized solar cells (DSSCs)
}

\author{
Roman A. Irgashev, ${ }^{* a, b}$ Arseny A. Karmatsky, ${ }^{a, b}$ Grigory A. Kim, ${ }^{a}$ Alexey A. Sadovnikov, ${ }^{c}$ Viktor V. Emets, ${ }^{d}$ Vitaly A. \\ Grinberg, ${ }^{d}$ Vladimir K. Ivanov, ${ }^{c, e}$ Sergey A. Kozyukhin, ${ }^{c, e}$ Gennady L. Rusinov, ${ }^{a, b}$ and Valery N. Charushin ${ }^{a, b}$
}

a Postovsky Institute of Organic Synthesis, Ural Division of the Russian Academy of Sciences, Ekaterinburg, 620990, Russia

${ }^{\mathrm{b}}$ Ural Federal University named after the First President of Russia, B. N. Yeltsin, Ekaterinburg, 620002, Russia

' Kurnakov Institute of General and Inorganic Chemistry RAS, Moscow, 11999, Russia

${ }^{\mathrm{d}}$ Frumkin Institute of Physical Chemistry and Electrochemistry RAS, Moscow, 119071, Russia

e Department of Chemistry, National Research Tomsk State University, Tomsk, 634050, Russia

E-mail: irgashev@ios.uran.ru

Received 09-21-2017

Accepted 01-22-2017

Published on line 04-21-2017

\section{Abstract}

New metal-free sensitizers (IK 3-6), based on the thieno[2,3-b]indole ring system, bearing various aliphatic substituents at the nitrogen atom (electron-donating part), several thiophene units ( $\pi$-bridge linker) and 2-cyanoacrylic acid (the electron-accepting and anchoring group) have been synthesized for application in dye-sensitized solar cells (DSSCS). The relationship between the IK dye structure and efficiency of the corresponding DSSC has been elucidated. Power conversion efficiency (PCE) up to 6.3\% (short-circuit photocurrent density (JsC) $19.0 \mathrm{~mA} \mathrm{~cm}{ }^{-2}$, open-circuit voltage (Voc) $0.59 \mathrm{~V}$, and fill factor (FF) 56.4\%) were obtained for the DSSC, based on 2-cyano-3-\{5-[8-(2-ethylhexyl)-8H-thieno[2,3b]indol-2-yl]thiophen-2-yl\}acrylic acid (IK 3), which proved to be a highly synthetic available compound, under simulated AM $1.5 \mathrm{G}$ irradiation $\left(100 \mathrm{~mW} \mathrm{~cm}^{-2}\right)$, thus indicating that thieno[2,3-b]indole-based organic dyes are perspective candidates for DSSCs.

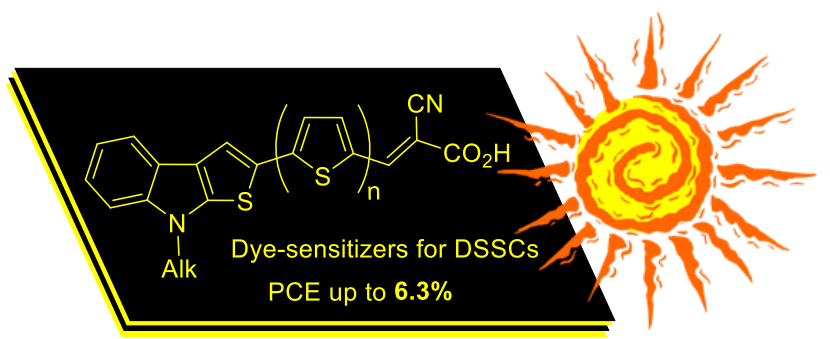

Keywords: Thieno[2,3-b]indole, electron-rich heterocycles, push-pull structure, metal-free dyes, photovoltaic properties, dye-sensitized solar cells 


\section{Introduction}

Photovoltaic devices, based on crystalline, inorganic semiconductors, have reached impressive characteristics of their conversion efficiencies: over $28 \%$ in single-junction, and $37.9 \%$ in multi-junction device architectures under full illumination. ${ }^{1}$ However, this class of photovoltaics has disadvantages, concerning their high production and energy costs, resulting in a long financial payback time. The original paper by O'Regan and Grätzel, published in $1991,{ }^{2}$ revealed that a relatively high efficiency for the conversion of solar radiation to electricity can be achieved using dye-sensitized solar cells (DSSCs) based on organometallic dyes adsorbed on nanocrystalline semiconductor photoelectrodes (e.g., $\mathrm{TiO}_{2}, \mathrm{SnO}_{2}, \mathrm{ZnO}$, NiO). Since then, great attention has been paid to development of organic dye sensitizers as the crucial components of DSSCs.

High values of power conversion efficiency (PCE) (up to 11.5\%) have been reached for DSSCs, based on polypyridyl ruthenium complexes. ${ }^{3}$ However, their applications are limited owing to the high cost of this noble metal. In comparison with Ru-dyes, metal-free organic dyes have larger molar extinction coefficients $(\varepsilon)$ and their facile synthesis and structural versatility enable tuning of the absorption wavelength and HOMO-LUMO energy levels. This is why a whole number of publications have been dedicated to the design of metal-free organic dyes and their examination in DSSCs during the last years. ${ }^{4-12}$

In general, an organic dye molecule usually consists of an electron-donating part, a $\pi$-linker and an electron-accepting fragment, making the so-called "push-pull" structure. Push-pull dyes, which are based on electron-rich heterocyclic derivatives, such as carbazole, ${ }^{13,14}$ indolo[3,2-b]carbazole,,$^{15}$ and thieno[3,2-b]indole units, ${ }^{16}$ with oligothiophene $\pi$-linkers and a 2-cyanoacetic acid fragment, as the acceptor moiety proved to exhibit high PCE values (up to 8.3\%). In our previous publication, we reported the facile synthesis of push-pull dyes IK 1 and IK $\mathbf{2}$ with a new electron-donating thieno[2,3-b]indole system. The sensitization potential of these dyes in DSSCs was also established (Figure 1). ${ }^{17}$

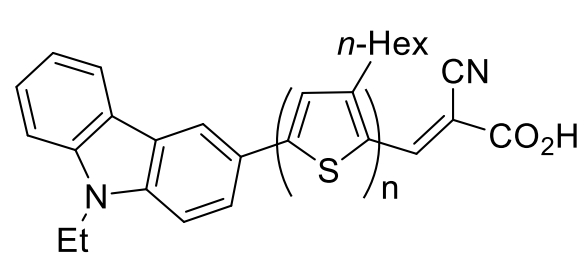

MK 1-8

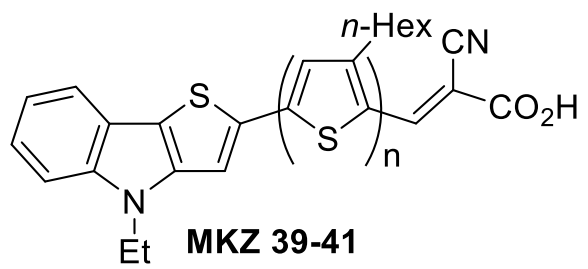

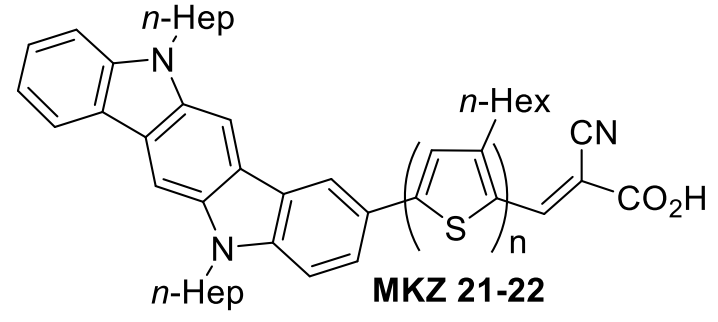

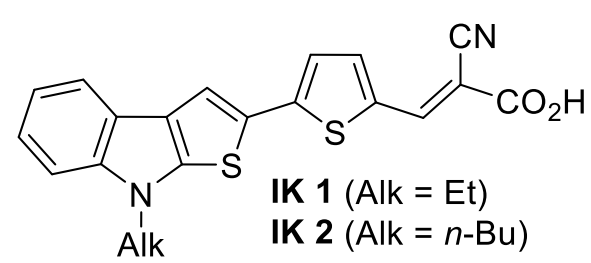

Figure 1. Structures of push-pull dyes with the electron-rich heterocyclic donors.

Herein, we report on structural tuning of thieno[2,3-b]indole dyes by introducing a long alkyl-chain on the nitrogen atom of this heterocyclic system to suppress aggregation of dye molecules, ${ }^{18,19}$ as well as by incorporation of thiophene units into the structure as $\pi$-linkers to enhance their light-harvesting ability. Effects of the structure of organic dyes on photovoltaic characteristics of the fabricated DSSCs have been elucidated. 


\section{Results and Discussion}

\section{Synthesis of the IK dyes}

A new dye-sensitizer IK 3, bearing a 2-ehtylhexyl substituent at N-1 of the thieno[2,3-b]indole ring system, was obtained according to the same procedure, used for the synthesis of dyes IK $\mathbf{1}$ and IK 2, described in the recently published paper. ${ }^{17}$ Namely, 2-(thien-2-yl)-substituted thieno[2,3-b]indole 1 a was formylated by using the Vilsmeier-Haack reaction to form the corresponding aldehyde $2 \mathrm{a}$. This aldehyde was condensed with 2 cyanoacetic acid to give the target dye IK 3, bearing a branched aliphatic chain at the nitrogen atom and only one thiophene unit, as a $\pi$-bridge linker for this push-pull system (Scheme 1).

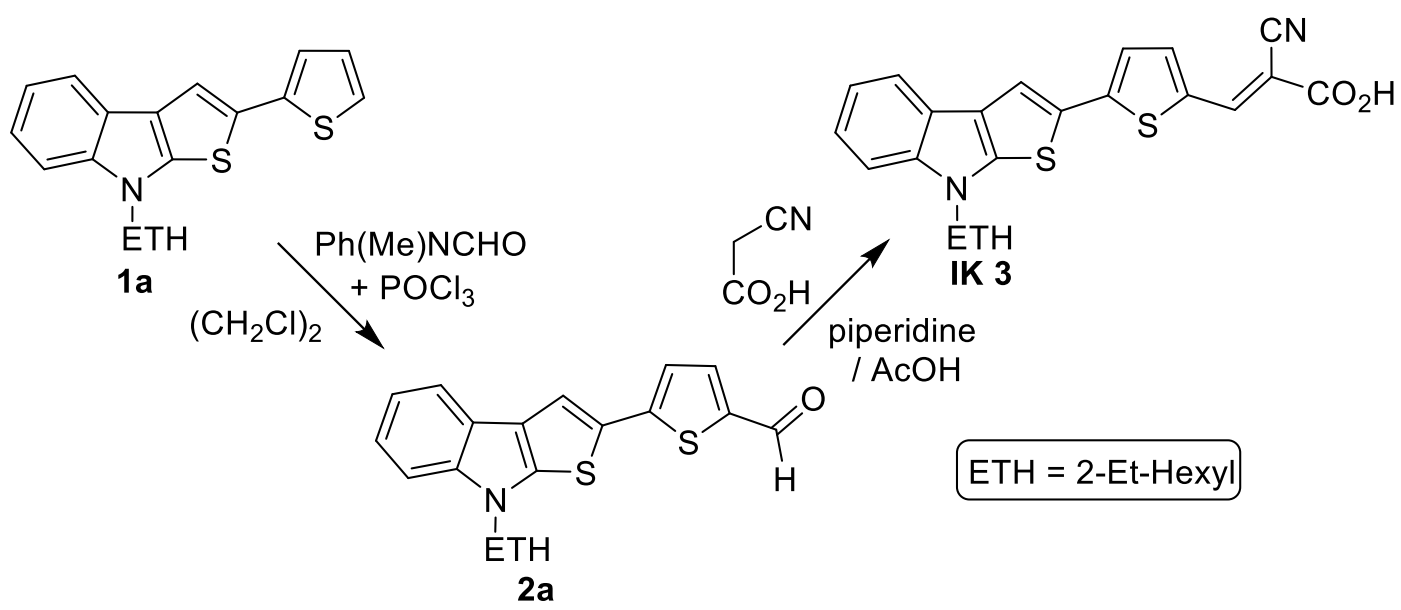

Scheme 1. The synthesis of thieno[2,3-b]indole dye IK 3.

A similar synthetic strategy was used to obtain thieno[2,3- $b$ ]indole dyes with a larger number of thiophene units in the $\pi$-bridge linker. Potential dye precursors $\mathbf{1 c}$ and $\mathbf{1 d}$ with 2,2'-bithiophene and 2,2':5',2"terthiophene moieties were prepared according to the recently reported protocol for the synthesis of 2(het)aryl-substituted thieno[2,3-b]indoles. ${ }^{20}$ Interestingly, the cyclization of indolin-2-one $\mathbf{3 b}$ with the Lawesson's reagent (LR) in refluxing toluene led to the formation of the protodebrominated thieno[2,3-


synthesis of compounds $\mathbf{1} \mathbf{c}, \mathbf{d}$. We believe that the reductive cyclization of the intermediate $\mathbf{3 b}$ by action of the Lawesson's reagent was accompanied by reductive debromination, which takes place, for instance, on treatment of 2-bromothiophenes with zinc powder in glacial acetic acid. ${ }^{21}$ Moreover, attempts to synthesize compound $\mathbf{2 - B r - 1 b}$ through direct bromination of thieno[2,3-b]indole $\mathbf{1} \mathbf{b}$ failed. To solve this problem, prefunctionalization of the 5-bromothien-2-yl part of indolin-2-one $\mathbf{3 b}$ through the Stille cross-coupling reaction with 2-(tributylstannyl)thiophene was performed successfully, thus affording 2,2'-bithiophene-containing intermediate $3 \mathrm{c}$ in $86 \%$ yield.

The target thieno[2,3-b]indole $\mathbf{1 c}$ was obtained from compound $\mathbf{3 c}$ using the typical cyclization procedure with the Lawesson's reagent. The terthiophene precursor $\mathbf{1} \mathbf{d}$ was prepared through a similar cyclization of the corresponding indolin-2-one $\mathbf{3 d}$, obtained by condensation of $N$-( $n$-butyl)isatin with 5-acetylterthiophene (Scheme 2). The latter compound was synthesized by acetylation of 2,2':5',2"-terthiophene according to a slightly modified literature procedure. ${ }^{22}$ 

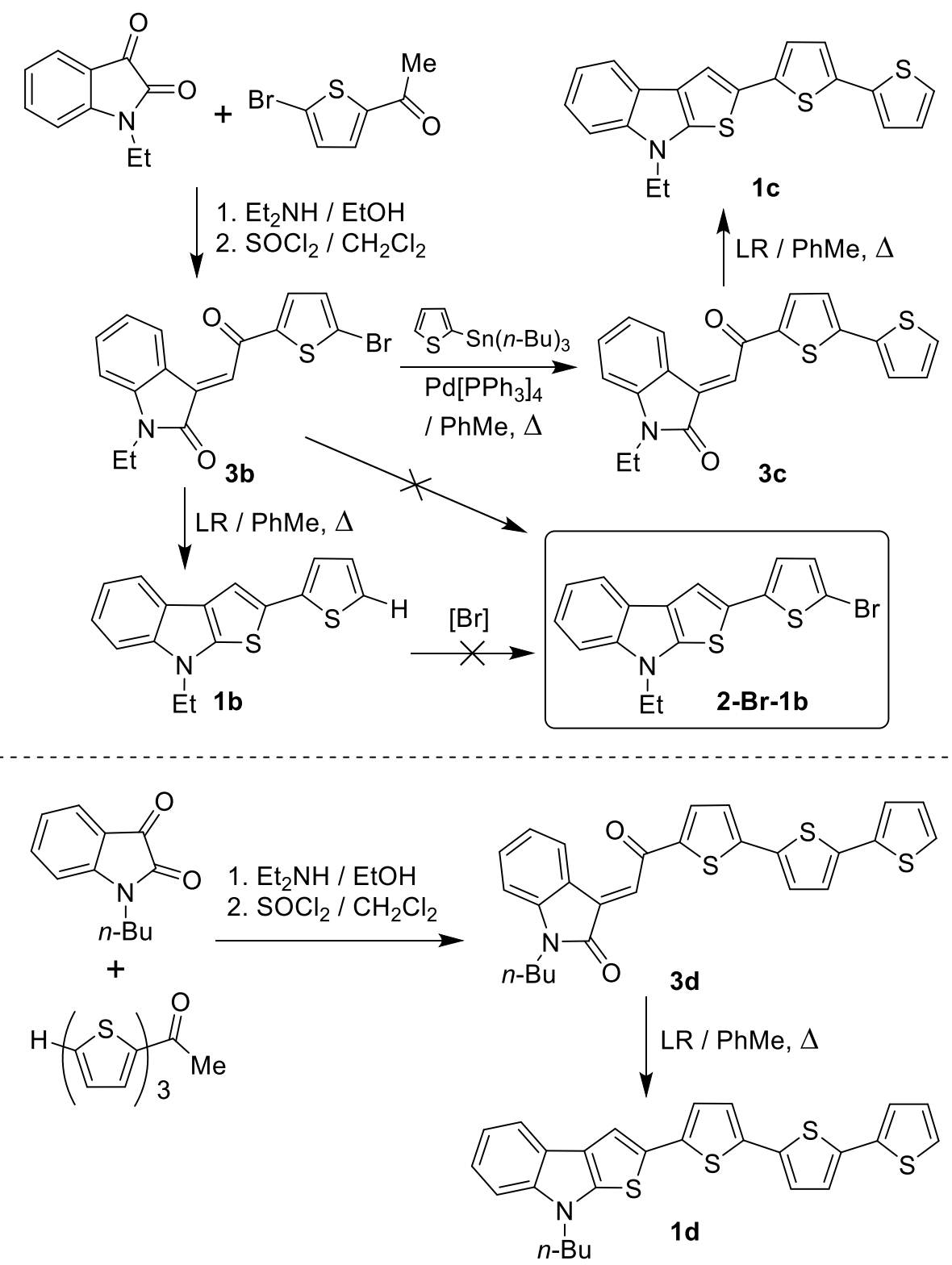

Scheme 2. Synthesis of thieno[2,3-b]indoles $\mathbf{1 c}$ and $\mathbf{1 d}$ with bi- and tertthiophene moieties.

The Vilsmeier-Haack formylation of compounds $\mathbf{1 c}$ and $\mathbf{1 d}$ was supposed to be the next step in the synthesis of the target dyes. Unfortunately, attempts to formylate the thieno[2,3-b]indoles in this way failed as rapid degradation of the starting materials $\mathbf{1} \mathbf{c}$ and $\mathbf{1} \mathbf{d}$ occured on treatment with the Vilsmeier complex. As such, an alternative synthetic strategy was elaborated to produce thieno[2,3-b]indole dyes with an expanded $\pi$-conjugated system. The approach exploited included the conversion of thieno[2,3-b]indoles $\mathbf{1 b}$ and $\mathbf{1 e}$ into the corresponding stannanes $\mathbf{1 B}$ and $\mathbf{1 E}$, followed by the Stille cross-coupling reaction of intermediate 1B with 5-bromothiophene-2-carbaldehyde or intermediate $\mathbf{1 E}$ with 5'-bromo-[2,2'-bithiophene]-5-carbaldehyde to produce thienaldehydes $\mathbf{2} \mathbf{b}$ and $\mathbf{2 d}$, respectively. In a similar manner, thieno[2,3-b]indole $\mathbf{1} \mathbf{c}$, bearing 2,2'bithiophene moiety, was transformed into aldehyde 2c. Finally, new thieno[2,3-b]indole dyes IK 4-6 were synthesized through the Knoevenagel condensation of functional thienaldehydes $\mathbf{2} \mathbf{b}$ - $\mathbf{d}$ with 2 -cyanoacetic acid in glacial acetic acid under reflux with piperidine, as the catalyst (Scheme 3). 

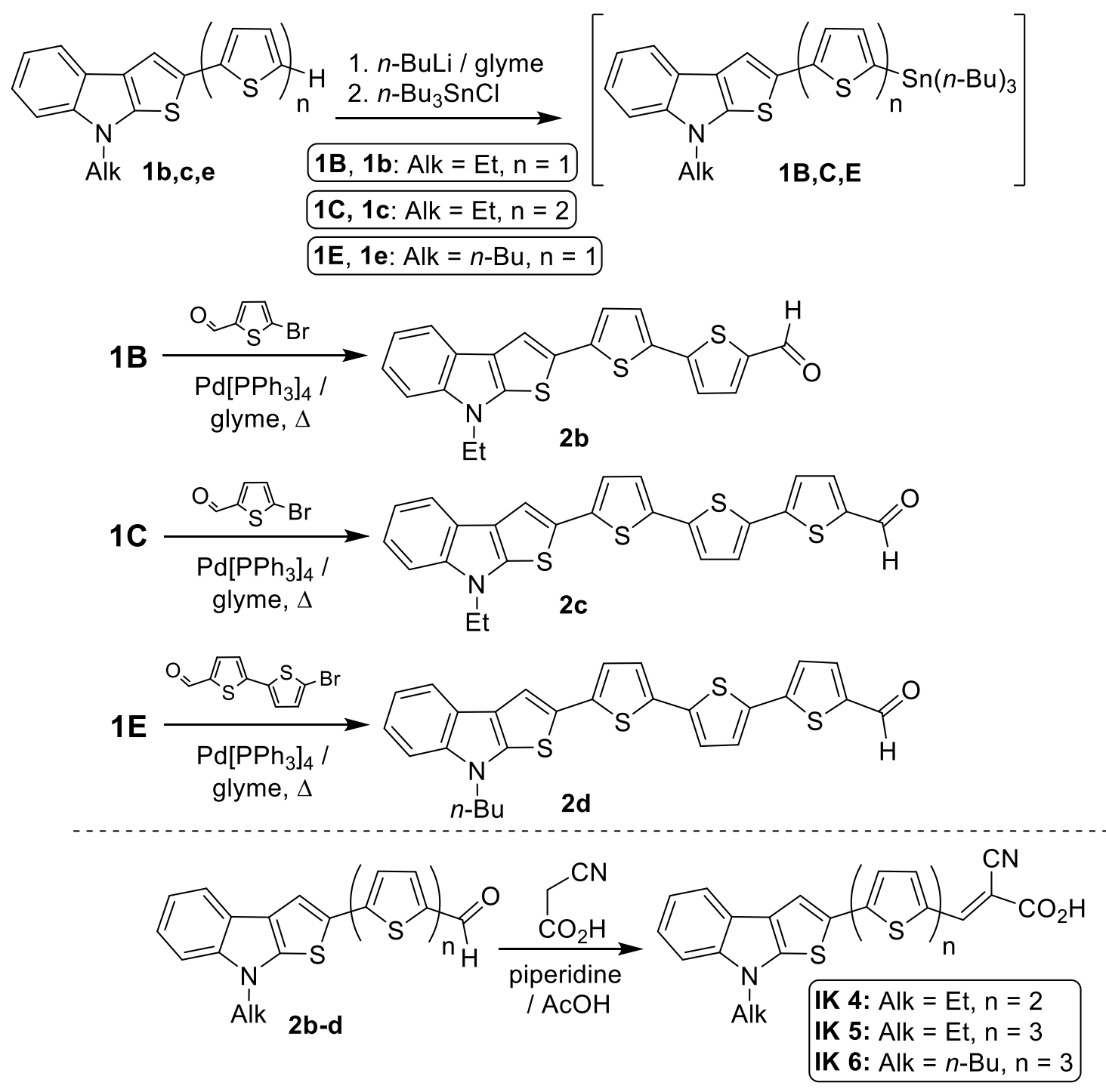

Scheme 3. Synthesis of 2-thienaldehydes $\mathbf{2} \mathbf{b}-\mathbf{d}$ and the corresponding dyes IK 4-6.

\section{Optical and electrochemical measurements}

UV-vis absorption spectra of the dyes IK 3-6 in THF are shown in the Figure 2, and the spectral data are summarized in the Table 1 . The $350-400 \mathrm{~nm}$ bands can be attributed to the localized $\pi \rightarrow \pi^{*}$ electron transition. The main absorption bands in the visible region of $\sim 400-600 \mathrm{~nm}$ with a high molar absorption are likely to originate from intramolecular charge transfer (ICT) transitions from the thieno[2,3-b]indole donating part of the molecules to electron-withdrawing fragment of 2-cyanoacrylic acid. The bathochromic shift caused by an increase in the number of thiophene units in the $\pi$-bridge can be observed due to $\pi \rightarrow \pi^{*}$ electron transition, that changes from $320 \mathrm{~nm}$ (IK 3) and $364 \mathrm{~nm}$ (IK 4) to $398 \mathrm{~nm}$ (IK 5 and IK 6). Also, this increase makes some bathochromic shift to ICT, but it can be observed only between one (IK 3) and two (IK 4) thiophene moieties. It is noteworthy that all dyes show a high visible molar extinction coefficient (from 42141 to $48773 \mathrm{M}^{-1} \mathrm{~cm}^{-1}$ ), thus indicating their good light-harvesting capability. However, the value of molar extinction in the group of these dyes is enhanced slightly, when the number of thiophenes units in the $\pi$-bridge linker is increased from one to three. 


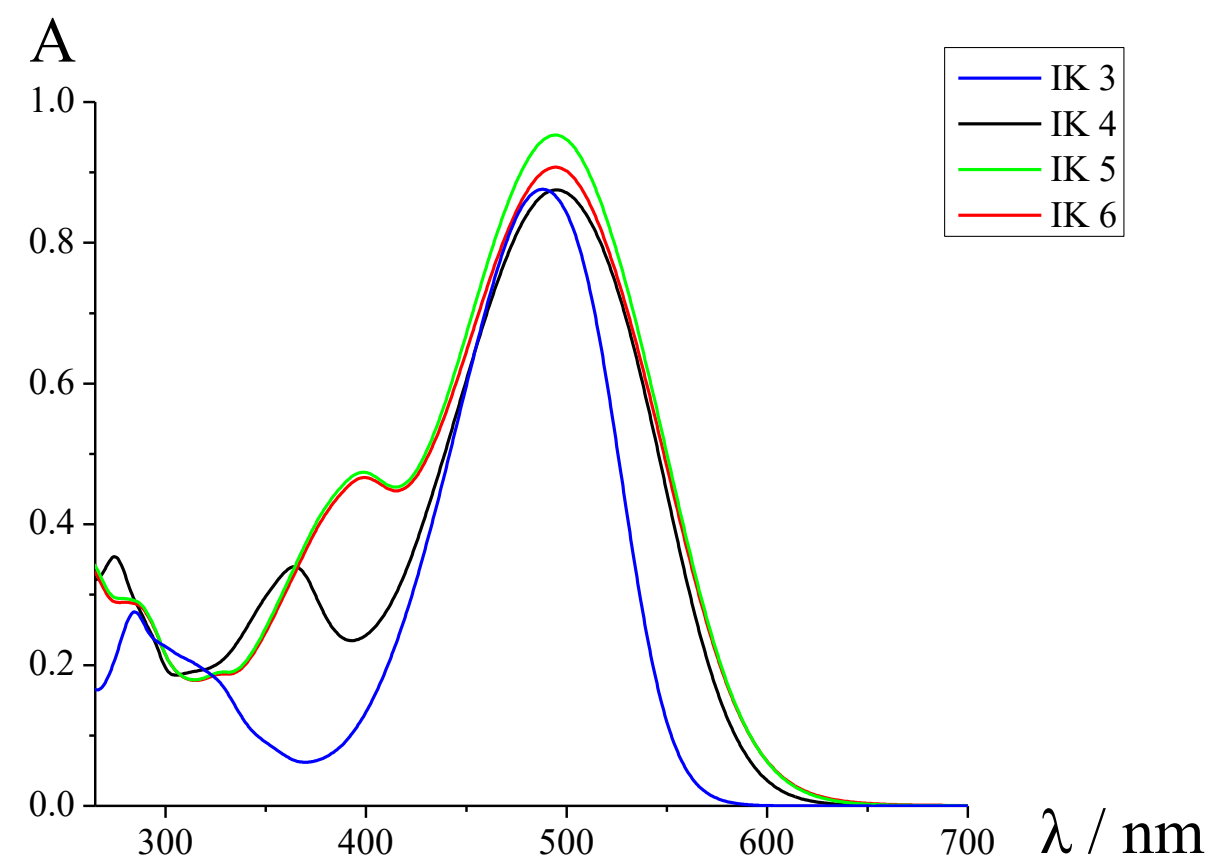

Figure 2. UV-vis absorption spectra of the IK dyes in $2 \cdot 10^{-5} \mathrm{M}$ THF solution.

The diffuse reflectance spectra (DRS) of the IK 3-6 solid compounds are shown in the Figure 3 as KubelkaMunk function vs light energy. The Kubelka-Munk equation is expressed as follows:

$$
F\left(R_{d}\right)=\frac{\left(1-R_{d}\right)^{2}}{2 R_{d}}
$$

$R_{d}$ is the absolute reflectance of the sample layer. The optical band gap energies ( $E_{\text {gap }}{ }^{\text {opt }}$ ) were estimated from the extrapolation of the linear parts of corresponding curves to $F\left(R_{d}\right)=0$. These data are summarized in the Table 1. The energy band gap can be easily tuned by increasing the number of tiophene units in the $\pi$-bridges, and the values of $E_{\text {gap }}{ }^{\text {opt }}$ lie in the range from 1.51 to $1.82 \mathrm{eV}$. These values indicate the prospects of using the studied compounds as light-harvesting materials.

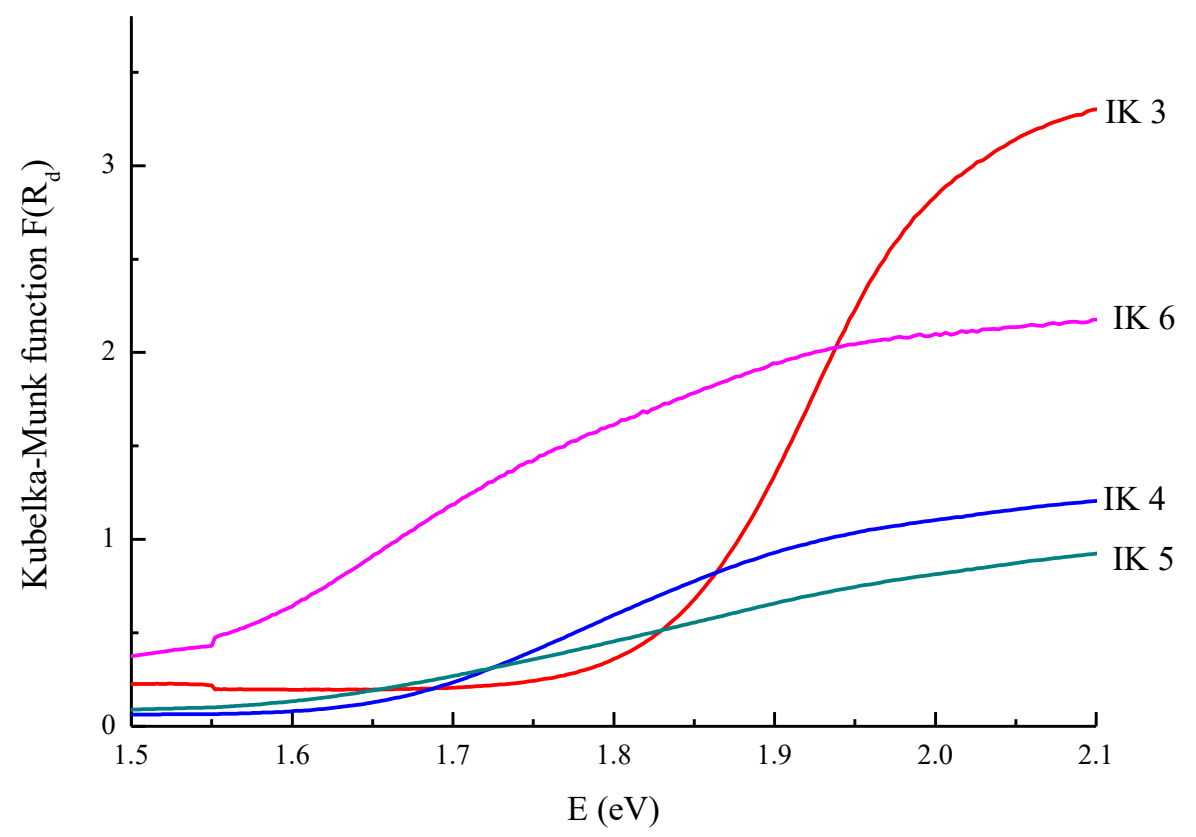


Figure 3. Reflectance spectra of solid samples IK 3-6

Table 1. Optical and electrochemical properties of the IK dyes

\begin{tabular}{ccccccc}
\hline Dye & $\lambda_{\max }(\mathrm{nm})$ & $\varepsilon\left(\mathrm{M}^{-1} \mathrm{~cm}^{-1}\right)$ & $E_{\text {gap }}{ }^{\text {opt }}(\mathrm{eV})^{a}$ & $E_{\text {Ox }}{ }^{\text {onset }}(\mathrm{V})^{b}$ & $E_{\text {HOMO }}(\mathrm{eV})^{c}$ & $E_{\text {LUMO }}(\mathrm{eV})^{d}$ \\
\hline IK 3 & 488 & 42820 & 1.82 & 0.47 & -5.12 & -3.30 \\
IK 4 & 495 & 42141 & 1.64 & 0.41 & -5.06 & -3.42 \\
IK 5 & 494 & 48773 & 1.59 & 0.33 & -4.98 & -3.39 \\
IK 6 & 494 & 44426 & 1.51 & 0.33 & -4.98 & -3.47 \\
\hline
\end{tabular}

${ }^{a} E_{\text {gap }}{ }^{\text {opt }}$ was estimated from the diffuse reflectance spectra of the IK dyes in solid state. ${ }^{b} \mathrm{The} \mathrm{Ag} / \mathrm{AgNO} 3$ reference electrode was calibrated using ferrocene/ferrocenium redox couple $\left(\mathrm{Fc} / \mathrm{Fc}^{+}\right) .{ }^{c} E_{\mathrm{HOMO}}(\mathrm{eV})=-\left[E_{\mathrm{Ox}}{ }^{\text {onset }}\right.$ - $\left.E_{1 / 2}\left(\mathrm{Fc} / \mathrm{Fc}^{+}\right)+4.8\right]$, where $E_{1 / 2}\left(\mathrm{Fc} / \mathrm{Fc}^{+}\right)$is the half-wave potential of the $\mathrm{Fc} / \mathrm{Fc}^{+}$couple against the $\mathrm{Ag} / \mathrm{Ag}^{+}$ electrode. It was defined at $0.15 \mathrm{~V}$ in the calibration experiment. ${ }^{d} E_{\mathrm{LUMO}}=E_{\mathrm{HOMO}}+E_{\text {gap }}{ }^{\text {opt }}$.

Electrochemical characteristics of the dyes IK 3-6 were measured by cyclic voltammetry (CV) in a $\mathrm{THF} / \mathrm{MeCN}(v / v, 1: 1)$ solution of $0.1 \mathrm{M} \mathrm{LiClO}_{4}$, as the supporting electrolyte at a scan rate of $100 \mathrm{mV} / \mathrm{s}$, and the results obtained are listed in the Table 1. Thus, the HOMO energy levels of sensitizers IK 3-6, that correspond to the first oxidation potential of each dye, were determined from the CV data.



Figure 4. HOMO and LUMO energy levels diagram of dyes IK 3-6.

The LUMO energy levels of these dyes were calculated from the optical energy band gaps, estimated from

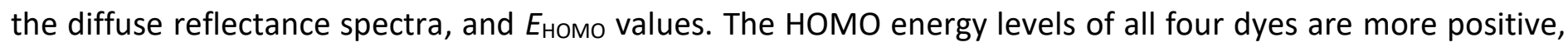
than the $\mathrm{I}^{-} / \mathrm{I}_{3}^{-}$redox couple $(-4.9 \mathrm{eV})$, making possible regeneration of oxidized dye molecules after injection of excited electrons into $\mathrm{TiO}_{2}$ electrode. On the other hand, the latter process is energetically permitted for each of these dyes because of their LUMO energy levels are more negative than the conduction edge of the $\mathrm{TiO}_{2}(-3.9 \mathrm{eV})$ (Figure 4).

\section{Photovoltaic measurements}

Photovoltaic properties of DSSCs. DSSCs were fabricated using the synthesized dyes IK 3-6, as photosensitizers, and their photovoltaic properties were measured under standard global AM 1.5 irradiation

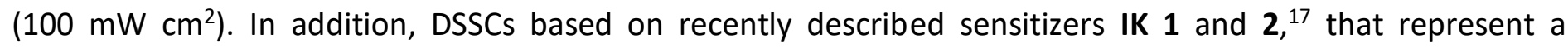
structurally close series of thieno[2,3-b]indole dyes, were also tested under similar experimental conditions. It is important to note that only formal applicability of dyes IK $\mathbf{1}$ and $\mathbf{2}$ as sensitizers for DSSCs has been shown in our previous work. ${ }^{17}$ In particular, PCE values of the obtained solar cells were very low (PCE $=0.37 \%$ for IK 1; 
PCE $=0.79 \%$ for IK 2). These low PCE values were attributed to a number of defects of $\mathrm{TiO}_{2}$ photoanodes, which were manufactured and used in that study. ${ }^{17}$

In contrast, the manufacturing technique of $\mathrm{TiO}_{2}$ electrodes has been significantly improved during current research, which allowed us to obtain photovoltaic devises based on the investigated dyes with better PCE characteristics. Furthermore, the photosensitize capabilities of all IK dyes have been compared with commercial ruthenium dye N3 cell performance. The photocurrent - voltage curves are depicted in the Figure 5 , and the detailed parameters of short-circuit current density $\left(\mathrm{J}_{S C}\right)$, open-circuit voltage $\left(\mathrm{V}_{O C}\right)$, fill factor (FF) as well as total power conversion efficiency (PCE) are summarized in the Table 2.



Figure 5. Photocurrent -voltage curves of the DSSCs based on the IK dyes.

Table 2. Photovoltaic performances of DSSCs based on the IK dyes and N3

\begin{tabular}{ccccc}
\hline Dye & $\mathrm{J}_{S C}\left(\mathrm{~mA} \mathrm{~cm}^{-2}\right)$ & $\mathrm{V}_{O C}(\mathrm{~V})$ & $\mathrm{FF}(\%)$ & PCE (\%) \\
\hline IK 1 & 3.6 & 0.67 & 59.5 & 1.4 \\
IK 2 & 25.8 & 0.48 & 38.3 & 4.8 \\
IK 3 & 19.0 & 0.59 & 56.4 & 6.3 \\
IK 4 & 19.9 & 0.39 & 43.5 & 3.4 \\
IK 5 & 4.7 & 0.47 & 60.5 & 1.3 \\
IK 6 & 6.6 & 0.37 & 55.8 & 1.4 \\
N3 $^{a, b}$ & $<16.5 \pm 3.0>$ & $<0.71 \pm 0.04>$ & $<53.3 \pm 6.6>$ & $<6.1 \pm 0.1>$ \\
\hline
\end{tabular}

${ }^{a} \mathbf{N} 3$ - cis-diisothiocyanato-bis(2,2'-bipyridyl-4,4'-dicarboxylic acid) ruthenium(II). ${ }^{b}$ For reference dye parallel measurements were performed on five identical photoanodes that allowed to calculate the error.

The formal relationship between the structure of the IK dyes and PCE of solar cells is visualized in the Figure 6. A significant increase of PCEs of cells based on dyes IK 1-3, having one thiophene unit $(n=1)$ in the $\pi$ bridge linker, was observed with increasing length of aliphatic chain (Alk = Et, Bu and ETH) at the nitrogen atom of their thieno[2,3-b]indole donating part. The DSSC based on dye IK $\mathbf{3}$ showed the highest PCE of $6.3 \%$ with $\mathrm{J}_{S C}$ of $19.0 \mathrm{~mA} \mathrm{~cm}{ }^{-2}, \mathrm{~V}_{O C}$ of $0.59 \mathrm{~V}$ and $\mathrm{FF}$ of $56.4 \%$. Furthermore, the PCE value for DSSC with IK 3 was comparable with that of the cell based on the commercially available ruthenium dye N3, one of the well- 
known standard dyes. At the same time, the efficiency of cells based on IK 1, IK 4, and IK 5 (Alk = Et; $n=1,2$ and 3 , respectively) proved first to be increasing, and then decreasing sharply, while more thiophene units are involved gradually into the structure of $\pi$-bridge linker. However, replacement of the ethyl group at the nitrogen atom of thieno[2,3-b]indole donating part (compound IK 5, PCE $=1.3 \%$ ) with the butyl substituent (IK $6, \mathrm{PCE}=1.4 \%$ ) does not influence the PCE values of the cells.
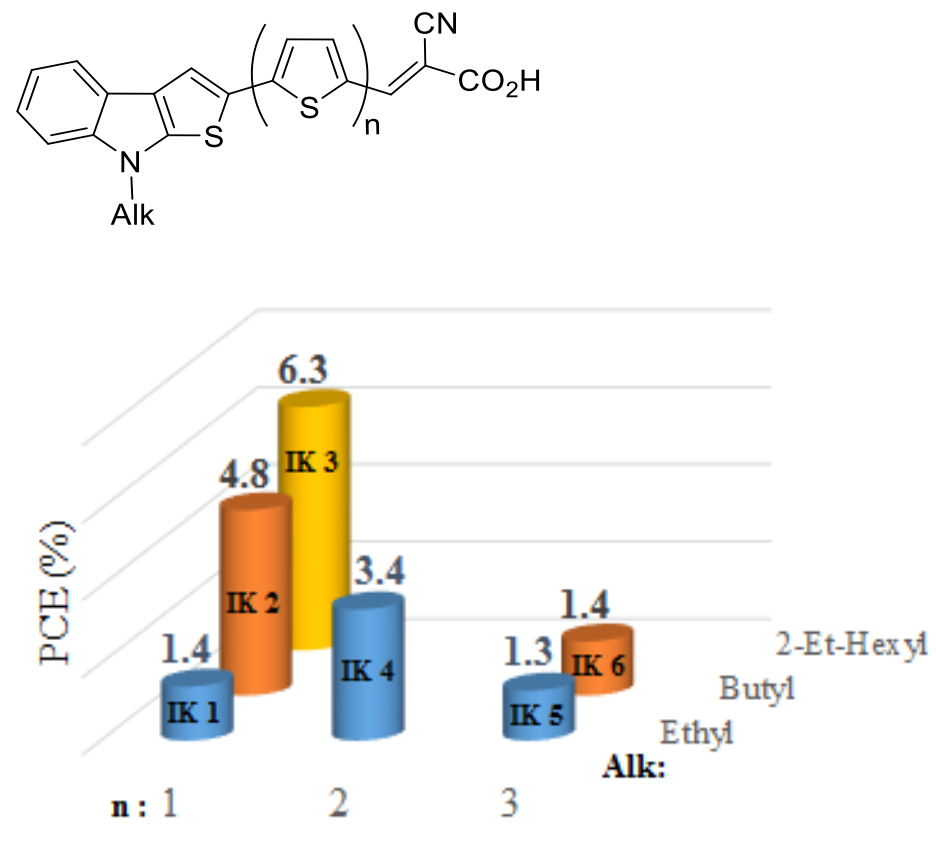

Figure 6. Relationship between the IK dye structure and PCE values of the related DSSCs.

Thus, DSSCs based on dyes IK 1, IK 5 and IK 6 were characterized by low PCE values linked with a poor photocurrent. The main reason for low $J_{S C}$ values is proposed to be that dyes IK $\mathbf{1}, \mathbf{5}$ and $\mathbf{6}$, having an insufficient size of aliphatic chain in their donating part and a high coplanar and $\pi$-conjugated structure, were capable of self-aggregation on the surface of $\mathrm{TiO}_{2}$ photoanode, thus decreasing electron-injection yields. Indeed, it has previously been reported in the literature that unfavorable aggregation of dye molecules on $\mathrm{TiO}_{2}$ film is the reason of excited-state quenching of the dyes, and as a consequence it leads to losses during the electron-injection process. ${ }^{23-26}$

\section{Transients of photocurrent}

Figure 7 shows the transient of the photocurrent for DSSC with a photoanode sensitized by the dye IK $\mathbf{3}$. One can see that the potential shifted rapidly into the negative direction in case of illuminating photoanode with IK 3, which indicated a high rate of accumulation of injected electrons in the conduction band of $\mathrm{nc}-\mathrm{TiO}_{2}$. The photocurrent density initially enhanced steeply under illumination with light output of $100 \mathrm{~mW} \mathrm{~cm}^{-2}$, and then the photocurrent stablized. The transient of the photocurrent has a good rectangular form, as one can see in the Figure 7. This indicated that there were no diffusion limitations for dye IK $\mathbf{3}$ regeneration and imposition of the dark electrochemical processes in case of the iodine-iodide mediator system. This result was confirmed by the absence of cathodic current at any potential of short circuit under dark conditions. 


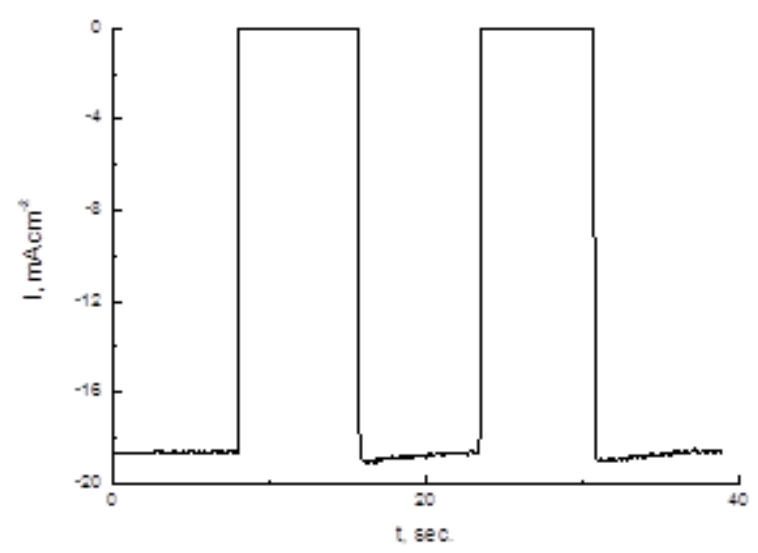

Figure 7. Time dependence of photocurrent for DSSC with photoanode with dye IK $\mathbf{3}$ in the dark, and upon irradiation with light $\left(100 \mathrm{~mW} / \mathrm{cm}^{2}\right)$; scans recorded in acetonitrile solution in the presence of $0.5 \mathrm{M}$ Lil + 0.05 $\mathrm{MI}_{2}$ at the potential of short circuit current density.

\section{Conclusions}

We have developed new organic dyes of the thieno[2,3-b]indole family, and used them successfully for sensitization of $\mathrm{TiO}_{2}$ films in the DSSCs. The optical and redox properties of these dyes were investigated. All of these dyes show a strong light-harvesting ability in the visible region, and the LUMO and HOMO levels (estimated from their electrochemical and optical data) were suitably located for electron-injection and regeneration processes in the solar cell. An aliphatic substituent, in respect of its length and branching, located in the electron-donating part of sensitizers, decisively influenced solar cell efficiency, since it inhibits aggregation of the dye molecules onto $\mathrm{TiO}_{2}$ surface by creating steric hindrances upon their adsorption. Indeed, the best result of solar energy-to-electricity conversion efficiency of $6.3 \%$ was achieved for the device based on the dye IK 3, having 2-Et-hexyl chain at the nitrogen atom of thieno[2,3-b]indole donor and only one thiophene unit in its $\pi$-bridge. In contrast, PCE values of the cells with dyes IK 5 (1.3\%) and IK 6 (1.4\%), containing $2,2^{\prime}: 5^{\prime}, 2^{\prime \prime}$-terthiophene moiety, as the $\pi$-bridge linker, were significantly lower due to intermolecular $\pi$-stacking and aggregation processes in these dyes, proceeding on photoanode surface. It can be suggested that one of plausible ways to improve properties of these dyes is structural protection of oligothiophene $\pi$-bridge by long aliphatic chains, as it has previously been done for many metal-free dyes based on different electron-rich heterocycles or triarylamines. ${ }^{4,27-29}$ On the other hand, dye-sensitizer IK 3 is a synthetic available compound due to its preparation route is rather short and does not require any transition metal-catalysts or pyrophoric reagents, and this dye appears to be a very promising for DSSC application. In this regards, results reported herein indicate that the thieno[2,3-b]indole ring system is very perspective as electron-donating block for the further engineering of new sensitizers for high-performance DSSCs.

\section{Experimental Section}

General. ${ }^{1} \mathrm{H}$ and ${ }^{13} \mathrm{C}$ NMR spectra were obtained on Bruker DRX-400 and AVANCE-500 spectrometers, with TMS as the internal standard. The ${ }^{13} \mathrm{C}$ NMR spectrum of dye IK 6 could not be determined due to a poor 
solubility of this dye in a range of deuterated solvents. Elemental analyses were carried out on a Eurovector EA 3000 automated analyzer. Melting points were determined on a Boetius apparatus and were not corrected. IR spectra of samples (solid powders) were recorded on a Spectrum One Fourier transform IR spectrometer (Perkin Elmer), equipped with a diffuse reflectance attachment (DRA). UV-visible spectra were recorded for a $2 \cdot 10^{-5} \mathrm{M}$ THF solution with Shimadzu UV-2401PC spectrophotometer. Cyclic voltammetry of the IK dyes was carried out for their $1 \cdot 10^{-3} \mathrm{M}$ THF/MeCN (1:1) solutions with Metrohm Autolab PGSTAT128N potentiostat using a standard three-electrode cell, which was equipped with a platinum working electrode, a $\mathrm{Ag} / \mathrm{AgNO} \mathrm{O}_{3}$ $(0.01 \mathrm{M})$ reference electrode, and a glassy carbon rod counter electrode. A three-electrode PECC-2 cell was used for photo-electrochemical measurements. The photoanode served as the working electrode and a platinum wire with the surface area of $5 \mathrm{~cm}^{2}$ was used as the auxiliary electrode. In both electrochemical cells, a silver wire was used as the reference electrode. All potentials are given relative to this reference electrode. The voltammetric measurements were performed with an IPC Pro MF potentiostat under AM 1.5 global one sun of illumination ( $100 \mathrm{~mW} \mathrm{~cm}^{-2}$ ), provided by a solar simulator (Newport 96000$)$. The illumination power at different distances was determined with a Nova apparatus (OPHIR-SPIRICON Inc.). The illuminated photoanode area was $0.125 \mathrm{~cm}^{2}$. The illumination was performed from the side of $\mathrm{a} \mathrm{TiO}_{2}$ photoanode with the adsorbed dye. The time dependence of the photoanode and cathode potentials under the open-circuit conditions and the photocurrents at the short-circuit potential (transients) were measured under both illumination and in dark.

$\mathrm{TiO}_{2}$ photoelectrode preparation. The preparation of photoelectrode was performed by adopting doctorblade technique on a conducting glassTCO22-15 $\left(2.9 \times 2.9 \mathrm{~cm}^{2}\right.$ pieces $)$ coated with a conductive fluorinated tin oxide (specific surface resistivity about $15 \Omega / s q$, Solaronix), which was purified by aging in a sulfochromic mixture, followed by ultra-sonication in organic solvents (isopropanol and acetone) and distilled water, and then dried at $50{ }^{\circ} \mathrm{C}$ in air. Application of Ti-nanoxide D/SP paste (Solaronix), comprising a nanocrystalline titanium dioxide, was performed by the adopting doctor-blade procedure, using a stencil with a square hole of $2.0 \times 2.0 \mathrm{~cm}$ ( $90 \mu \mathrm{m}$ depth). After application of the paste, raw photoanodes were dried at $50{ }^{\circ} \mathrm{C}$ in air, and then calcined in a muffle furnace at $450{ }^{\circ} \mathrm{C}$ for $1 \mathrm{~h}$ (heating rate $3^{\circ} \mathrm{C} / \mathrm{min}$, in air) The thickness of thus obtained titanium dioxide film was about $15 \mu \mathrm{m}$. Sensitizing of titanium dioxide was performed by soaking photoanodes in 5.10-4 M THF solutions of dyes IK 3-6 for $24 \mathrm{~h}$.

DSSCs properties test. To measure photocurrent-voltage (J-V) characteristics, the DSSC was illuminated by light with energy of $100 \mathrm{~mW} \cdot \mathrm{cm}^{-2}$ (AM 1.5) from a $150 \mathrm{~W}$ solar simulator (Newport, 96000). A computercontrolled IPC Pro MF potentiostat was employed to collect the J-V curves.

General procedure for the synthesis of indoline-2-ones $(3 b, d)$. The solution of 1-alkylisatin (3 mmol), corresponding acetylthiophene $(3 \mathrm{mmol})$ and $N, N$-diethylamine $(0.062 \mathrm{~mL}, 0.6 \mathrm{mmol})$ in EtOH $(15 \mathrm{~mL}) \mathrm{was}$ stirred at room temperature for $36 \mathrm{~h}$. The resulting mixture was concentrated under reduced pressure and the residue was dissolved in dry $\mathrm{CH}_{2} \mathrm{Cl}_{2}(10 \mathrm{~mL}) . \mathrm{SOCl}_{2}(0.28 \mathrm{~mL}, 3.9 \mathrm{mmol})$ was then added to the solution and the mixture was stirred at room temperature for $2 \mathrm{~h}$. After that it was concentrated under reduced pressure and the residue was recrystallized from EtOH affording indolin-2-ones $\mathbf{3 b}, \mathbf{d}$ as dark-red needles.

3-[2-(5-Bromothiophen-2-yl)-2-oxoethylidene]-1-ethylindolin-2-one (3b). Red crystals; yield $750 \mathrm{mg}$ (69\%); $\mathrm{mp} 126-128{ }^{\circ} \mathrm{C} ;{ }^{1} \mathrm{H}$ NMR $\left(400 \mathrm{MHz}, \mathrm{DMSO}-d_{6}\right) \delta 8.34(\mathrm{~d}, J 7.4 \mathrm{~Hz}, 1 \mathrm{H}), 8.01(\mathrm{~d}, J 4.1 \mathrm{~Hz}, 1 \mathrm{H}), 7.66(\mathrm{~s}, 1 \mathrm{H}), 7.50-$ $7.43(\mathrm{~m}, 2 \mathrm{H}), 7.13(\mathrm{~d}, J 7.9 \mathrm{~Hz}, 1 \mathrm{H}), 7.06(\mathrm{t}, J 7.5 \mathrm{~Hz}, 1 \mathrm{H}), 3.77(\mathrm{q}, J 7.1 \mathrm{~Hz}, 2 \mathrm{H}), 1.18(\mathrm{t}, J 7.2 \mathrm{~Hz}, 3 \mathrm{H}) ;{ }^{13} \mathrm{C} \mathrm{NMR}$ $\left(126 \mathrm{MHz}, \mathrm{DMSO}-d_{6}\right) \delta 181.50,166.35,146.80,145.21,136.67,135.25,133.42,132.97,127.63,123.95$, $123.78,122.24,119.40,109.15,34.29,12.50$; IR (DRA): 457, 492, 547, 573, 597, 645, 674, 688, 704, 748, 781, 
$790,817,855,884,905,960,990,1015,1028,1060,1075,1107,1132,1152,1236,1287,1317,1352,1384$, 1409, 1466, 1521, 1598, 1619, 1646, 1712, 1767, 1805, 1922, 1957, 2935, 2987, 3094, 3125, $3402 \mathrm{~cm}^{-1}$. Anal. Calcd. for $\mathrm{C}_{16} \mathrm{H}_{12} \mathrm{BrNO}_{2} \mathrm{~S}: \mathrm{C}, 53.05 ; \mathrm{H}, 3.34 ; \mathrm{N}, 3.87$. Found: $\mathrm{C}, 53.14 ; \mathrm{H}, 3.36 ; \mathrm{N}, 3.91 \%$.

3-[2-([2,2':5',2"-Terthiophen]-5-yl)-2-oxoethylidene]-1-butylindolin-2-one (3d). Red crystals; yield $655 \mathrm{mg}$ (46\%); mp 158-160 ${ }^{\circ} \mathrm{C} ;{ }^{1} \mathrm{H}$ NMR $\left(400 \mathrm{MHz}, \mathrm{CDCl}_{3}\right) \delta 8.64(\mathrm{~d}, J 7.7 \mathrm{~Hz}, 1 \mathrm{H}), 7.85(\mathrm{~d}, J 4.1 \mathrm{~Hz}, 1 \mathrm{H}), 7.76(\mathrm{~s}, 1 \mathrm{H})$, 7.37 (td, J 7.6, $1.0 \mathrm{~Hz}, 1 \mathrm{H}), 7.31-7.27(\mathrm{~m}, 2 \mathrm{H}), 7.25-7.21(\mathrm{~m}, 2 \mathrm{H}), 7.14(\mathrm{~d}, J 3.8 \mathrm{~Hz}, 1 \mathrm{H}), 7.08-7.02(\mathrm{~m}, 2 \mathrm{H}), 6.82$ (d, J $7.8 \mathrm{~Hz}, 1 \mathrm{H}), 3.76(\mathrm{t}, J 7.3 \mathrm{~Hz}, 2 \mathrm{H}), 1.74-1.64(\mathrm{~m}, 2 \mathrm{H}), 1.48-1.36(\mathrm{~m}, 2 \mathrm{H}), 0.97(\mathrm{t}, J 7.3 \mathrm{~Hz}, 3 \mathrm{H}) ;{ }^{13} \mathrm{C} \mathrm{NMR}(101$ $\left.\mathrm{MHz}_{1} \mathrm{CDCl}_{3}\right) \delta 181.9,168.0,147.2,145.7,144.3,139.2,136.9,136.5,134.7,134.2,132.8,128.9,128.1,126.9$, $125.4,124.7,124.6,124.5,124.4,122.7,120.4,108.4,39.9,29.5,20.2,13.7$; IR (DRA): 459, 489, 535, 559, 574, $606,625,637,649,658,690,711,750,780,796,838,883,918,939,977,1062,1085,1101,1134,1153,1205$, $1242,1259,1294,1361,1390,1468,1500,1617,1647,1713,1739,1873,1902,2169,2293,2499,2690,2739$, 2860, 2927, 2960, 3021, 3079, 3177, $3404 \mathrm{~cm}^{-1}$. Anal. Calcd. for $\mathrm{C}_{26} \mathrm{H}_{21} \mathrm{NO}_{2} \mathrm{~S}_{3}$ : C, 65.65; H, 4.45; N, 2.94. Found: C, $65.61 ; \mathrm{H}, 4.57 ; \mathrm{N}, 3.06 \%$.

Indolin-2-one 3c. A solution of compound $3 \mathbf{b}(1.81 \mathrm{~g}, 5 \mathrm{mmol}), 2$-(tributylstannyl)thiophene $(1.75 \mathrm{~mL}, 5.5$ $\mathrm{mmol})$ and $\mathrm{Pd}\left(\mathrm{Ph}_{3} \mathrm{P}\right)_{4}(0.29 \mathrm{~g}, 0.25 \mathrm{mmol})$ in toluene $(30 \mathrm{~mL})$ was stirred at $100{ }^{\circ} \mathrm{C}$ for $10 \mathrm{~h}$ under an argon atmosphere. Then the mixture was stirred with $10 \%$ aqueous solution of $\mathrm{KF}(70 \mathrm{~mL})$ for $5 \mathrm{~h}$. Toluene layer was separated, filtered through a silicagel pad and the solvent was removed under reduced pressure. The residue was recrystallized from $\mathrm{EtOH} / \mathrm{CH}_{2} \mathrm{Cl}_{2}$ giving red crystals of indolin-2-one $3 \mathrm{c}$.

3-[2-([2,2'-Bithiophen]-5-yl)-2-oxoethylidene]-1-ethylindolin-2-one (3c). Red crystals; yield $1.57 \mathrm{~g}$ (86\%); mp 136-137 ${ }^{\circ} \mathrm{C} ;{ }^{1} \mathrm{H}$ NMR (400 MHz, DMSO-d $) \delta 8.39(\mathrm{~d}, J 7.7 \mathrm{~Hz}, 1 \mathrm{H}), 8.12(\mathrm{~d}, J 4.1 \mathrm{~Hz}, 1 \mathrm{H}), 7.73(\mathrm{~d}, J 5.0 \mathrm{~Hz}, 1 \mathrm{H})$, $7.71(\mathrm{~s}, 1 \mathrm{H}), 7.64(\mathrm{~d}, J 3.6 \mathrm{~Hz}, 1 \mathrm{H}), 7.50(\mathrm{~d}, J 4.1 \mathrm{~Hz}, 1 \mathrm{H}), 7.48-7.44(\mathrm{~m}, 1 \mathrm{H}), 7.21-7.18(\mathrm{~m}, 1 \mathrm{H}), 7.13(\mathrm{~d}, J 7.8 \mathrm{~Hz}$, $1 \mathrm{H}), 7.09-7.04(\mathrm{~m}, 1 \mathrm{H}), 3.78(\mathrm{q}, J 7.2 \mathrm{~Hz}, 2 \mathrm{H}), 1.19(\mathrm{t}, J 7.1 \mathrm{~Hz}, 3 \mathrm{H}) ;{ }^{13} \mathrm{C} \mathrm{NMR}\left(126 \mathrm{MHz}, \mathrm{DMSO}-d_{6}\right) \delta 181.8$, 166.5, 146.6, 145.1, 143.1, 136.0, 135.9, 135.2, 133.2, 128.9, 128.5, 127.6, 127.0, 125.5, 124.7, 122.2, 119.5, 109.1, 34.3, 12.5; IR (DRA): 456, 488, 548, 577, 594, 625, 646, 653, 696, 747, 760, 785, 801, 821, 845, 857, 901, $936,971,988,1018,1031,1048,1079,1105,1132,1152,1161,1188,1239,1255,1289,1313,1349,1387$, $1421,1445,1465,1508,1611,1635,1706,1789,1941,2679,2876,2936,2977,3077,3109,3402 \mathrm{~cm}^{-1}$. Anal. Calcd. for $\mathrm{C}_{20} \mathrm{H}_{15} \mathrm{NO}_{2} \mathrm{~S}_{2}: \mathrm{C}, 65.73 ; \mathrm{H}, 4.14 ; \mathrm{N}, 3.83$. Found: $\mathrm{C}, 65.54 ; \mathrm{H}, 4.28 ; \mathrm{N}, 3.64 \%$.

General procedure for the synthesis of thieno[2,3-b]indoles (1c and $1 \mathrm{~d})$. The mixture of indolin-2-one 3c or 3d $(2 \mathrm{mmol})$ and the Lawesson's reagent $(0.81 \mathrm{~g}, 2 \mathrm{mmol})$ in dry toluene $(10 \mathrm{~mL})$ was refluxed for $1 \mathrm{~h}$. Upon refluxing the color of the solution turns from dark-red to yellow. The resulting solution was concentrated under reduced pressure and the residue was purified by column chromatography (silica gel, $\mathrm{CH}_{2} \mathrm{Cl}_{2} /$ hexane $1: 2)$ to give yellow powders of thieno[2,3-b]indoles $\mathbf{1 c}$ and $\mathbf{1 d}$, respectively.

2-([2,2'-Bithiophen]-5-yl)-8-ethyl-8H-thieno[2,3-b]indole (1c). Yellow powder; yield $430 \mathrm{mg}(59 \%) ; \mathrm{mp} \mathrm{130-}$ $131{ }^{\circ} \mathrm{C} ;{ }^{1} \mathrm{H}$ NMR $(500 \mathrm{MHz}$, DMSO-d 6$) \delta 7.84(\mathrm{~d}, J 7.8 \mathrm{~Hz}, 1 \mathrm{H}), 7.74(\mathrm{~s}, 1 \mathrm{H}), 7.61(\mathrm{~d}, J 8.3 \mathrm{~Hz}, 1 \mathrm{H}), 7.53(\mathrm{dd}, J 5.1$, $1.1 \mathrm{~Hz}, 1 \mathrm{H}), 7.33$ (dd, J 3.6, $1.1 \mathrm{~Hz}, 1 \mathrm{H}), 7.30-7.25(\mathrm{~m}, 2 \mathrm{H}), 7.21(\mathrm{~d}, J 3.8 \mathrm{~Hz}, 1 \mathrm{H}), 7.17(\mathrm{td}, J 7.6,0.9 \mathrm{~Hz}, 1 \mathrm{H}), 7.11$ (dd, J 5.1, 3.6 Hz, 1H), 4.35 (q, J 7.2 Hz, 2H), 1.41 (t, J 7.2 Hz, 3H); ${ }^{13} \mathrm{C}$ NMR (126 MHz, DMSO-d $)$ ) $\delta 141.3,140.9$, 136.9, 136.1, 134.0, 128.4, 127.4, 125.4, 124.8, 123.9, 123.1, 122.2, 121.3, 119.6, 119.3, 115.4, 110.0, 40.4, 13.6; IR (DRA): 470, 667, 700, 744, 777, 796, 813, 838, 845, 881, 896, 926, 943, 963, 1014, 1052, 1081, 1129, $1159,1188,1206,1230,1252,1276,1330,1349,1401,1424,1438,1453,1466,1480,1505,1522,1555,1570$, $1592,1632,1671,1688,1743,1767,1797,1885,1924,2874,2935,2981,3059,3100 \mathrm{~cm}^{-1}$. Anal. Calcd. for $\mathrm{C}_{20} \mathrm{H}_{15} \mathrm{NS}_{3}$ : C, 65.72; $\mathrm{H}, 4.14 ; \mathrm{N}, 3.83$. Found: $\mathrm{C}, 65.71 ; \mathrm{H}, 4.10 ; \mathrm{N}, 3.65 \%$. 
2-([2,2':5',2"'-Terthiophen]-5-yl)-8-butyl-8H-thieno[2,3-b]indole (1d). Yellow needles; yield $340 \mathrm{mg}(36 \%) ; \mathrm{mp}$ 145-147 ${ }^{\circ} \mathrm{C} ;{ }^{1} \mathrm{H}$ NMR $\left(500 \mathrm{MHz}, \mathrm{CDCl}_{3}\right) \delta 7.78(\mathrm{~d}, J 7.7 \mathrm{~Hz}, 1 \mathrm{H}), 7.46(\mathrm{~s}, 1 \mathrm{H}), 7.36(\mathrm{~d}, J 8.2 \mathrm{~Hz}, 1 \mathrm{H}), 7.30-7.26(\mathrm{~m}$, $1 \mathrm{H}), 7.21(\mathrm{dd}, J 5.1,1.1 \mathrm{~Hz}, 1 \mathrm{H}), 7.20-7.16(\mathrm{~m}, 2 \mathrm{H}), 7.08(\mathrm{~d}, J 3.8 \mathrm{~Hz}, 1 \mathrm{H}), 7.06(\mathrm{dd}, J 3.7,2.8 \mathrm{~Hz}, 2 \mathrm{H}), 7.03-7.00$ $(\mathrm{m}, 2 \mathrm{H}), 4.19(\mathrm{t}, J 7.1 \mathrm{~Hz}, 2 \mathrm{H}), 1.96-1.87(\mathrm{~m}, 2 \mathrm{H}), 1.44-1.35(\mathrm{~m}, 2 \mathrm{H}), 0.96(\mathrm{t}, J 7.4 \mathrm{~Hz}, 3 \mathrm{H}) ;{ }^{13} \mathrm{C} \mathrm{NMR}(126 \mathrm{MHz}$, $\left.\mathrm{CDCl}_{3}\right) \delta$ 142.9, 141.6, 138.1, 137.2, 136.2, 136.0, 134.6, 128.3, 127.9, 124.5, 124.4, 124.2, 123.9, 123.7, 123.5, $122.8,122.1,122.1,119.6,119.6,119.4,115.0,109.4,46.1,30.9,20.3,13.7$; IR (DRA): 463, 497, 554, 582, 607, $684,735,750,789,811,823,838,862,911,925,1016,1036,1068,1120,1116,1132,1209,1222,1236,1252$, $1267,1288,1332,1364,1380,1410,1424,1435,1456,1480,1499,1515,1541,1569,1606,1638,1747,1780$, $1872,1909,2680,2868,2928,2959,3070 \mathrm{~cm}^{-1}$. Anal. Calcd. for $\mathrm{C}_{26} \mathrm{H}_{21} \mathrm{NS}_{4}: \mathrm{C}, 65.64 ; \mathrm{H}, 4.45 ; \mathrm{N}, 2.94$. Found: C, 65.68; H, 4.37; N, 2.98\%.

5-[8-(2-Ethylhexyl)-8H-thieno[2,3-b] indol-2-yl]thiophene-2-carbaldehyde (2a). $\mathrm{POCl}_{3}(1.4 \mathrm{~mL}, 15 \mathrm{mmol}) \mathrm{was}$ added to a solution of $N$-methylformanilide $(1.85 \mathrm{~mL}, 15 \mathrm{mmol})$ in dry dichloroethane $(30 \mathrm{~mL})$ and the solution was stirred at room temperature for $30 \mathrm{~min}$. Thieno[2,3-b]indole $1 \mathrm{a}(1.84 \mathrm{~g}, 5 \mathrm{mmol})$ was added to the Vilsmeier reagent and the resulting mixture was stirred at room temperature for $96 \mathrm{~h}$. Then the mixture was vigorously stirred with $5 \% \mathrm{NaHCO}_{3}(60 \mathrm{~mL})$ for $3 \mathrm{~h}$. The organic layer was separated and the solvent was evaporated under a reduced pressure. The residue was purified by column chromatography (silica gel, $\left.\mathrm{CH}_{2} \mathrm{Cl}_{2}\right)$ and aldehyde $2 \mathrm{a}$ was obtained as a yellow powder; yield $1.56 \mathrm{~g}(79 \%) ; \mathrm{mp} 105-106{ }^{\circ} \mathrm{C} ;{ }^{1} \mathrm{H} \mathrm{NMR}(500 \mathrm{MHz}$, DMSO- $\left.d_{6}\right) \delta 9.85(\mathrm{~s}, 1 \mathrm{H}), 8.05(\mathrm{~s}, 1 \mathrm{H}), 7.97(\mathrm{~d}, J 4.0 \mathrm{~Hz}, 1 \mathrm{H}), 7.87(\mathrm{~d}, J 7.7 \mathrm{~Hz}, 1 \mathrm{H}), 7.60(\mathrm{~d}, J 8.3 \mathrm{~Hz}, 1 \mathrm{H}), 7.46(\mathrm{~d}$, J $4.0 \mathrm{~Hz}, 1 \mathrm{H}), 7.34-7.28(\mathrm{~m}, 1 \mathrm{H}), 7.23-7.17(\mathrm{~m}, 1 \mathrm{H}), 4.20(\mathrm{~d}, J 7.6 \mathrm{~Hz}, 2 \mathrm{H}), 2.12-1.95(\mathrm{~m}, 1 \mathrm{H}), 1.41-1.13(\mathrm{~m}, 8 \mathrm{H})$, $0.87(\mathrm{t}, J 7.4 \mathrm{~Hz}, 3 \mathrm{H}), 0.80(\mathrm{t}, J 7.1 \mathrm{~Hz}, 3 \mathrm{H}) ;{ }^{13} \mathrm{C} \mathrm{NMR}\left(126 \mathrm{MHz}, \mathrm{CDCl}_{3}\right) \delta 182.0,149.3,144.9,142.2,139.8$, $137.6,127.0,123.8,122.6,122.0,121.8,119.9,119.6,117.6,109.6,50.4,39.0,30.7,28.5,24.1,22.9,13.9$, 10.6; IR (DRA): 414, 434, 480, 533, 569, 579, 592, 619, 664, 694, 716, 745, 767, 791, 808, 826, 854, 910, 940, $971,1015,1050,1132,1163,1191,1214,1234,1261,1305,1333,1366,1382,1437,1481,1506,1537,1571$, 1609, 1649, 1713, 1762, 1890, 1939, 2102, 2482, 2668, 2741, 2799, 2867, 2928, 3052, $3290 \mathrm{~cm}^{-1}$. Anal. Calcd. for $\mathrm{C}_{23} \mathrm{H}_{25} \mathrm{NOS}_{2}: \mathrm{C}, 69.83 ; \mathrm{H}, 6.37 ; \mathrm{N}, 3.54$. Found: C, 69.90; H, 6.14; N, 3.72\%.

General procedure for the synthesis of thieno[2,3-b]indole-based thienaldehydes (2b-d). 1.6 M Solution of $n$ butyllithium in hexane $(2.5 \mathrm{~mL}, 4 \mathrm{mmol})$ was added to the solution of thieno[2,3-b]indole $1 \mathbf{b}, 1 \mathrm{c}$ or 1 e $(2$ mmol) in dry glyme $(15 \mathrm{~mL})$ at $0{ }^{\circ} \mathrm{C}$ under an argon atmosphere. It was stirred at $0{ }^{\circ} \mathrm{C}$ for $1 \mathrm{~h}$ and then tributyltin chloride $(1.08 \mathrm{~mL}, 4 \mathrm{mmol})$ was added dropwise at $-40{ }^{\circ} \mathrm{C}$. The mixture was stirred at room temperature overnight. The appropriate bromo-containing 2-thienaldehyde $(2.2 \mathrm{mmol})$ and $\mathrm{Pd}\left(\mathrm{Ph}_{3} \mathrm{P}\right)_{4}(0.18 \mathrm{~g}$, $0.16 \mathrm{mmol}$ ) were added to the reaction mixture that was then heated at $95{ }^{\circ} \mathrm{C}$ for $8 \mathrm{~h}$. Then the mixture was stirred with $10 \% \mathrm{KF}(100 \mathrm{~mL})$ for $5 \mathrm{~h}$ and extracted with EtOAc $(100 \mathrm{~mL})$. Organic layer was separated and the solvent was removed under reduced pressure. The residue was purified by column chromatography (silica gel, $\mathrm{CH}_{2} \mathrm{Cl}_{2}$ ) affording red powders of aldehydes $\mathbf{2 b}$-d.

5'-(8-Ethyl-8H-thieno[2,3-b]indol-2-yl)-[2,2'-bithiophene]-5-carbaldehyde (2b). Red powder; yield $400 \mathrm{mg}$ (51\%); mp 124-126 ${ }^{\circ} \mathrm{C} ;{ }^{1} \mathrm{H}$ NMR $\left(500 \mathrm{MHz}, \mathrm{CDCl}_{3}\right) \delta 9.81(\mathrm{~s}, 1 \mathrm{H}), 7.78(\mathrm{~d}, J 7.7 \mathrm{~Hz}, 1 \mathrm{H}), 7.61(\mathrm{~d}, J 3.9 \mathrm{~Hz}, 1 \mathrm{H})$, $7.49(\mathrm{~s}, 1 \mathrm{H}), 7.36(\mathrm{~d}, J 8.2 \mathrm{~Hz}, 1 \mathrm{H}), 7.29(\mathrm{t}, J 7.6 \mathrm{~Hz}, 1 \mathrm{H}), 7.24-7.15(\mathrm{~m}, 3 \mathrm{H}), 7.02(\mathrm{~d}, J 3.8 \mathrm{~Hz}, 1 \mathrm{H}), 4.23(\mathrm{q}, J 7.3$ $\mathrm{Hz}, 2 \mathrm{H}), 1.50(\mathrm{t}, J 7.3 \mathrm{~Hz}, 3 \mathrm{H}) ;{ }^{13} \mathrm{C}$ NMR $\left(126 \mathrm{MHz}, \mathrm{CDCl}_{3}\right) \delta 182.3,147.1,142.7,141.2,141.1,141.0,137.4$, $132.9,127.6,126.9,123.8,123.6,122.8,122.3,122.0,119.8,119.5,115.8,109.3,40.9,13.7$; IR (DRA): 411, $423,471,500,553,574,603,671,700,733,780,814,841,879,917,1016,1046,1082,1132,1161,1224$, $1255,1333,1380,1453,1485,1506,1524,1555,1573,1666,1722,1839,1880,2091,2265,2482,2666,2798$, 2878, 2937, 2980, 3062, $3293 \mathrm{~cm}^{-1}$. MS (+ESI): Calcd. for $\mathrm{C}_{21} \mathrm{H}_{16} \mathrm{NOS}_{3} \mathrm{~m} / z 394.0389(\mathrm{M}+\mathrm{H})$, found $\mathrm{m} / \mathrm{z}$ $394.0383(\mathrm{M}+\mathrm{H})$. 
5"-(8-Ethyl-8H-thieno[2,3-b]indol-2-yl)-[2,2':5',2"-terthiophene]-5-carbaldehyde (2c). Red powder; yield 290 mg (30\%); mp 180-181 ${ }^{\circ} \mathrm{C} ;{ }^{1} \mathrm{H}$ NMR $\left(500 \mathrm{MHz}, \mathrm{CDCl}_{3}\right) \delta 9.86(\mathrm{~s}, 1 \mathrm{H}), 7.80(\mathrm{~d}, J 7.8 \mathrm{~Hz}, 1 \mathrm{H}), 7.67(\mathrm{~d}, J 3.9 \mathrm{~Hz}, 1 \mathrm{H})$, $7.50(\mathrm{~s}, 1 \mathrm{H}), 7.38(\mathrm{~d}, J 8.1 \mathrm{~Hz}, 1 \mathrm{H}), 7.32-7.28(\mathrm{~m}, 2 \mathrm{H}), 7.24(\mathrm{~d}, J 3.9 \mathrm{~Hz}, 1 \mathrm{H}), 7.20(\mathrm{t}, J 7.5 \mathrm{~Hz}, 1 \mathrm{H}), 7.14(\mathrm{~d}, J 3.8$ $\mathrm{Hz}, 1 \mathrm{H}), 7.12(\mathrm{~d}, J 3.8 \mathrm{~Hz}, 1 \mathrm{H}), 7.05(\mathrm{~d}, J 3.7 \mathrm{~Hz}, 1 \mathrm{H}), 4.28(\mathrm{q}, J 7.3 \mathrm{~Hz}, 2 \mathrm{H}), 1.53(\mathrm{t}, J 7.1 \mathrm{~Hz}, 3 \mathrm{H}) ;{ }^{13} \mathrm{C} \mathrm{NMR}(126$ $\left.\mathrm{MHz}_{\mathrm{CDCl}}\right) \delta 182.3,146.9,142.5,141.6,141.2,139.18,139.15,137.3,134.2,133.7,128.0,127.0,125.1$, 124.2, 124.0, 123.8, 122.8, 122.3, 122.2, 119.8, 119.5, 115.4, 109.3, 41.0, 13.8; IR (DRA): 417, 470, 512, 550, $575,636,670,740,790,810,858,892,906,924,945,1015,1049,1135,1161,1222,1250,1282,1331,1381$, $1402,1459,1502,1538,1572,1609,1672,1883,2113,2351,2496,2728,2809,2929,2965,3059,3309 \mathrm{~cm}^{-1}$. Anal. Calcd. for $\mathrm{C}_{25} \mathrm{H}_{17} \mathrm{NOS}_{4}$ : C, 63.13; $\mathrm{H}, 3.60 ; \mathrm{N}, 2.94$. Found: C, 63.18; $\mathrm{H}, 3.51 ; \mathrm{N}, 2.68 \%$.

5"-(8-Butyl-8H-thieno[2,3-b]indol-2-yl)-[2,2':5',2"-terthiophene]-5-carbaldehyde (2d). Red powder; yield 230 mg (23\%); mp 164-166 ${ }^{\circ} \mathrm{C} ;{ }^{1} \mathrm{H}$ NMR $\left(500 \mathrm{MHz}, \mathrm{CDCl}_{3}\right) \delta 9.86(\mathrm{~s}, 1 \mathrm{H}), 7.79(\mathrm{~d}, J 7.7 \mathrm{~Hz}, 1 \mathrm{H}), 7.67(\mathrm{~d}, J 3.9 \mathrm{~Hz}, 1 \mathrm{H})$, $7.50(\mathrm{~s}, 1 \mathrm{H}), 7.38(\mathrm{~d}, J 8.2 \mathrm{~Hz}, 1 \mathrm{H}), 7.33-7.27(\mathrm{~m}, 2 \mathrm{H}), 7.24(\mathrm{~d}, J 3.9 \mathrm{~Hz}, 1 \mathrm{H}), 7.22-7.18(\mathrm{~m}, 1 \mathrm{H}), 7.14(\mathrm{~d}, J 3.8 \mathrm{~Hz}$, $1 \mathrm{H}), 7.12(\mathrm{~d}, J 3.8 \mathrm{~Hz}, 1 \mathrm{H}), 7.05(\mathrm{~d}, J 3.8 \mathrm{~Hz}, 1 \mathrm{H}), 4.22(\mathrm{t}, J 7.1 \mathrm{~Hz}, 2 \mathrm{H}), 1.99-1.87(\mathrm{~m}, 2 \mathrm{H}), 1.49-1.36(\mathrm{~m}, 2 \mathrm{H})$, $0.97(t, J 7.4 \mathrm{~Hz}, 3 \mathrm{H}) ;{ }^{13} \mathrm{C}$ NMR $\left(126 \mathrm{MHz} \mathrm{CDCl}_{3}\right) \delta 182.3,146.9,143.0,141.7,141.6,139.18,139.15,137.3$, 134.2, 133.7, 128.0, 127.0, 125.1, 124.2, 123.9, 123.6, 122.8, 122.2, 122.0, 119.7, 119.5, 115.3, 109.4, 46.1, 30.9, 20.3, 13.7; IR (DRA): 435, 466, 511, 554, 586, 636, 667, 690, 715, 741, 782, 806, 845, 857, 895, 912, 927, $1016,1047,1066,1117,1136,1161,1226,1251,1267,1282,1332,1362,1378,1406,1456,1479,1504,1571$, 1609, 1659, 1742, 1890, 2110, 2497, 2725, 2796, 2872, 2932, 2958, 3061, $3295 \mathrm{~cm}^{-1}$. Anal. Calcd. for $\mathrm{C}_{27} \mathrm{H}_{21} \mathrm{NOS}_{4}$ : C, 64.38; H, 4.20; N, 2.78. Found: C, 64.33; H, 4.12; N, 2.72\%.

General procedure for the synthesis of thieno[2,3-b]indole-based dyes (IK 3-6). Piperidine (20 mg, 0.24 $\mathrm{mmol}$ ) was added to a solution of aldehyde $2 \mathrm{a}-\mathbf{d}(1 \mathrm{mmol}), 2$-cyanoacetic acid $(0.17 \mathrm{~g}, 2 \mathrm{mmol})$ in glacial AcOH $(15 \mathrm{~mL})$, and the resulting mixture was refluxed with stirring for $8 \mathrm{~h}$. After cooling, the precipitate was filtered and washed with EtOH, affording desired dye IK 3-6 as a black powder.

2-Cyano-3-\{5-[8-(2-ethylhexyl)-8H-thieno[2,3-b]indol-2-yl]thiophen-2-yl\}acrylic acid (IK 3). Black powder; yield $320 \mathrm{mg}$, (69\%); mp 270-272 ${ }^{\circ} \mathrm{C} ;{ }^{1} \mathrm{H}$ NMR (500 MHz, DMSO-d 6 ) $\delta 13.63$ (br. s, 1H), $8.46(\mathrm{~s}, 1 \mathrm{H}), 8.10(\mathrm{~s}, 1 \mathrm{H})$, $7.96(\mathrm{~d}, J 4.2 \mathrm{~Hz}, 1 \mathrm{H}), 7.91(\mathrm{~d}, J 7.7 \mathrm{~Hz}, 1 \mathrm{H}), 7.60(\mathrm{~d}, J 8.3 \mathrm{~Hz}, 1 \mathrm{H}), 7.51(\mathrm{~d}, J 4.0 \mathrm{~Hz}, 1 \mathrm{H}), 7.34-7.29(\mathrm{~m}, 1 \mathrm{H}), 7.22$ $-7.18(\mathrm{~m}, 1 \mathrm{H}), 4.21(\mathrm{~d}, J 7.6 \mathrm{~Hz}, 2 \mathrm{H}), 2.10-2.01(\mathrm{~m}, 1 \mathrm{H}), 1.41-1.12(\mathrm{~m}, 8 \mathrm{H}), 0.87(\mathrm{t}, J 7.4 \mathrm{~Hz}, 3 \mathrm{H}), 0.80(\mathrm{t}, J 7.1$ $\mathrm{Hz}, 3 \mathrm{H}) ;{ }^{13} \mathrm{C}$ NMR $(126 \mathrm{MHz} \text {, DMSO-d })_{6} \delta$ 163.9, 148.2, 146.2, 144.4, 142.2, 142.0, 132.2, 126.4, 123.9, 123.0, $122.9,121.2,120.0,119.8,118.9,116.8,110.4,96.3,49.6,38.3,29.9,27.9,23.5,22.4,13.8,10.5$; IR (DRA): $434,460,486,529,563,580,594,626,641,667,684,737,804,842,859,898,937,1058,1159,1223,1267$, 1328, 1368, 1430, 1479, 1516, 1577, 1682, 1919, 2216, 2520, $2960 \mathrm{~cm}^{-1}$. Anal. Calcd. for $\mathrm{C}_{26} \mathrm{H}_{26} \mathrm{~N}_{2} \mathrm{O}_{2} \mathrm{~S}_{2}: \mathrm{C}$, 67.50; H, 5.66; N, 6.06. Found: C, 67.43; H, 5.36; N, 6.06\%.

2-Cyano-3-[5'-(8-ethyl-8H-thieno[2,3-b]indol-2-yl)-[2,2'-bithiophen]-5-yl]acrylic acid (IK 4). Black powder; yield $370 \mathrm{mg}$, (80\%); mp 267-268 ${ }^{\circ} \mathrm{C} ;{ }^{1} \mathrm{H}$ NMR (400 MHz, DMSO-d 6 ) $\delta 13.68$ (br. s, 1H), 8.47 (s, $1 \mathrm{H}$ ), 7.97 (d, J $4.1 \mathrm{~Hz}, 1 \mathrm{H}), 7.89-7.81(\mathrm{~m}, 2 \mathrm{H}), 7.61(\mathrm{~d}, J 8.3 \mathrm{~Hz}, 1 \mathrm{H}), 7.59-7.54(\mathrm{~m}, 2 \mathrm{H}), 7.31-7.27(\mathrm{~m}, 2 \mathrm{H}), 7.18(\mathrm{t}, J 7.5 \mathrm{~Hz}$, $1 \mathrm{H}), 4.35$ (q, J $7.1 \mathrm{~Hz}, 2 \mathrm{H}), 1.41$ (t, J $7.2 \mathrm{~Hz}, 3 \mathrm{H}) ;{ }^{13} \mathrm{C}$ NMR (126 MHz, DMSO-d $) \delta$ 163.6, 146.2, 145.5, 142.1, 141.6, 141.1, 140.3, 133.6, 132.0, 131.9, 130.9, 128.2, 126.9, 124.7, 123.7, 123.4, 122.5, 121.3, 119.8, 119.4, 116.6, 110.2, 40.5, 13.5; IR (DRA): 452, 479, 547, 582, 598, 627, 676, 697, 749, 784, 879, 944, 1053, 1093, $1221,1330,1442,1481,1511,1572,1687,2217,2933 \mathrm{~cm}^{-1}$. Anal. Calcd. for $\mathrm{C}_{24} \mathrm{H}_{16} \mathrm{~N}_{2} \mathrm{O}_{2} \mathrm{~S}_{3} \cdot 0.3 \mathrm{H}_{2} \mathrm{O}: \mathrm{C}, 61.86 ; \mathrm{H}$, 3.59; N, 6.01. Found: C, 61.57; H, 3.41; N, 5.81\%.

2-Cyano-3-[5"'-(8-ethyl-8H-thieno[2,3-b]indol-2-yl)-[2,2':5',2"'-terthiophen]-5-yl]acrylic acid (IK 5). Black powder; yield $375 \mathrm{mg},(69 \%) ; \mathrm{mp}>300{ }^{\circ} \mathrm{C} ;{ }^{1} \mathrm{H}$ NMR (500 MHz, DMSO-d 6 ) $\delta 13.69$ (br. s, $\left.1 \mathrm{H}\right), 8.45$ (s, $\left.1 \mathrm{H}\right), 7.94$ (d, J $4.1 \mathrm{~Hz}, 1 \mathrm{H}), 7.83$ (d, J $7.7 \mathrm{~Hz}, 1 \mathrm{H}), 7.74(\mathrm{~s}, 1 \mathrm{H}), 7.59$ (d, J $8.3 \mathrm{~Hz}, 1 \mathrm{H}), 7.58-7.53(\mathrm{~m}, 2 \mathrm{H}), 7.36$ (dd, J 7.3, 3.8 
$\mathrm{Hz}, 2 \mathrm{H}), 7.28(\mathrm{t}, J 7.7 \mathrm{~Hz}, 1 \mathrm{H}), 7.21(\mathrm{~d}, J 3.8 \mathrm{~Hz}, 1 \mathrm{H}), 7.17(\mathrm{t}, J 7.4 \mathrm{~Hz}, 1 \mathrm{H}), 4.33(\mathrm{q}, J 7.1 \mathrm{~Hz}, 2 \mathrm{H}), 1.40(\mathrm{t}, J 7.2 \mathrm{~Hz}$, $3 \mathrm{H}) ;{ }^{13} \mathrm{C}$ NMR $\left(126 \mathrm{MHz}\right.$, DMSO- $\left.d_{6}\right) \delta 163.6,146.2,145.2,141.6,141.4,140.9,138.2,138.1,133.9,133.3$, 132.7, 128.2, 127.2, 126.1, 125.2, 125.0, 123.4, 123.3, 122.3, 121.3, 119.6, 119.3, 116.5, 115.8, 110.1, 97.9, 40.4, 13.6; IR (DRA): 470, 516, 550, 581, 598, 625, 649, 693, 737, 774, 864, 932, 1050, 1217, 1446, 1482, 1506, $1584,1682,2218,2981 \mathrm{~cm}^{-1}$. Anal. Calcd. for $\mathrm{C}_{28} \mathrm{H}_{18} \mathrm{~N}_{2} \mathrm{O}_{2} \mathrm{~S}_{4}: \mathrm{C}, 61.97 ; \mathrm{H}, 3.34 ; \mathrm{N}, 5.16$. Found: C, 61.72; $\mathrm{H}, 3.37$; $\mathrm{N}, 5.25 \%$.

3-[5"-(8-Butyl-8H-thieno[2,3-b]indol-2-yl)-[2,2':5',2"-terthiophen]-5-yl]-2-cyanoacrylic acid (IK 6). Black powder; yield $410 \mathrm{mg}$, (72\%); mp > $300{ }^{\circ} \mathrm{C} ;{ }^{1} \mathrm{H}$ NMR (400 MHz, DMSO-d 6 ) $\delta 13.75$ (br. s, 1H), 8.48 (s, $1 \mathrm{H}$ ), 7.98 (d, J $4.0 \mathrm{~Hz}, 1 \mathrm{H}), 7.84(\mathrm{~d}, J 7.7 \mathrm{~Hz}, 1 \mathrm{H}), 7.78(\mathrm{~s}, 1 \mathrm{H}), 7.64-7.58(\mathrm{~m}, 3 \mathrm{H}), 7.42(\mathrm{~d}, J 3.8 \mathrm{~Hz}, 1 \mathrm{H}), 7.40(\mathrm{~d}, J 3.9 \mathrm{~Hz}$, $1 \mathrm{H}), 7.32-7.24(\mathrm{~m}, 2 \mathrm{H}), 7.17(\mathrm{t}, J 7.4 \mathrm{~Hz}, 1 \mathrm{H}), 4.32(\mathrm{t}, J 6.9 \mathrm{~Hz}, 2 \mathrm{H}), 1.89-1.79(\mathrm{~m}, 2 \mathrm{H}), 1.37-1.25(\mathrm{~m}, 2 \mathrm{H}), 0.90$ (t, J $7.3 \mathrm{~Hz}, 3 \mathrm{H}$ ); IR (DRA): 433, 474, 550, 583, 737, 782, 863, 935, 1016, 1048, 1214, 1431, 1479, 1508, 1571, 1684, 2220, 2491, $2957 \mathrm{~cm}^{-1}$. Anal. Calcd. for $\mathrm{C}_{30} \mathrm{H}_{22} \mathrm{~N}_{2} \mathrm{O}_{2} \mathrm{~S}_{4} \cdot 0.3 \mathrm{H}_{2} \mathrm{O}: \mathrm{C}, 62.54 ; \mathrm{H}, 3.95 ; \mathrm{N}, 4.86$. Found: $\mathrm{C}, 62.37$; $\mathrm{H}, 3.80 ; \mathrm{N}, 4.50 \%$.

\section{Acknowledgements}

This research study was supported financially by the Russian Science Foundation (Project No. 16-13-10435).

\section{Supplementary Material}

${ }^{1} \mathrm{H}$ and ${ }^{13} \mathrm{C}$ NMR spectra of new compounds and CV curves of dyes IK 3-6.

\section{References}

1. Green, M. A.; Emery, K.; Hishikawa, Y.; Warta, W.; Dunlop E. D. Prog. Photovoltaics 2015, 23, 1-9. http://dx.doi.org./10.1002/pip.2573

2. O’Regan, B.; Grätzel, M. Nature 1991, 353, 737-740. http://dx.doi.org./10.1038/353737a0

3. Yum, J.-H.; Jung, I.; Baik, C.; Ko, J.; Nazeeruddin, M. K.; Grätzel, M. Energ. Environ Sci. 2009, 2, $100-102$. http://dx.doi.org./10.1039/B814863P

4. Liang, M.; Chen, J. Chem. Soc. Rev. 2013, 42, 3453-3488. http://dx.doi.org./10.1039/c3cs35372a

5. Liu, W. H.; Wu, I. C.; Lai, C. H.; Lai, C. H.; Chou, P. T.; Li, Y. T.; Chen, C. L.; Hsu, Y. Y.; Chi, Y. Chem. Commun. 2008, 5152-5154. http://dx.doi.org./10.1039/B808535H

6. Chen, B. S.; Chen, D. Y.; Chen, C. L.; Hsu, C. W.; Hsu, H. C.; Wu, K. L.; Liu, S. H.; Chou, P. T.; Chi, Y. J. Mater. Chem. 2011, 21, 1937-1945.

http://dx.doi.org./10.1039/COJM02433C

7. Li, R. Z.; Lv, X. J.; Shi, D.; Zhou, D. F.; Cheng, Y. M.; Zhang, G. L.; Wang, P. J. Phys. Chem. C 2009, 113, 74697479.

http://dx.doi.org./10.1021/ip900972v 
8. Zhang, G. L.; Bala, H.; Cheng, Y. M.; Shi, D.; Lv, X. J.; Yu, Q. J.; Wang, P. Chem. Commun. 2009, 2198-2200. http://dx.doi.org./10.1039/B822325D

9. Li, R. Z.; Liu, J. Y.; Cai, N.; Zhang, M.; Wang, P. J. Phys. Chem. B 2010, 114, 4461-4464. http://dx.doi.org./10.1021/jp101222s

10. W. Zeng, Y. Cao, Y. Bai, Y. Wang, Y. Shi, M. Zhang, F. Wang, C. Pan, P. Wang, Chem. Mater. 2010, 22, 19151925.

http://dx.doi.org./10.1021/cm9036988

11. Horiuchi, T.; Miura, H.; Uchida, S. Chem. Commun. 2003, 3036-3037.

http://dx.doi.org./10.1039/B307819A

12. Horiuchi, T.; Miura, H.; Sumioka, K.; Uchida, S. J. Am. Chem. Soc. 2004, 126, 12218-12219. http://dx.doi.org./10.1021/ja0488277

13. Wang, Z.-S.; Koumura, N.; Cui, Y.; Takahashi, M.; Sekiguchi, H.; Mori, A.; Kubo, T.; Furube, A.; Hara, K. Chem. Mater. 2008, 20, 3993-4003.

http://dx.doi.org./10.1021/cm8003276

14. Koumura, N.; Wang, Z.-S.; Miyashita, M.; Uemura, Y.; Sekiguchi, H.; Cui, Y.; Mori, A.; Mori, S.; Hara K. J. Mater. Chem. 2009, 19, 4829-4836.

http://dx.doi.org./10.1039/B905831A

15. Zhang, X.-H.; Wang, Z.-S.; Cui, Y.; Koumura, N.; Furube, A.; Hara, K. J. Phys. Chem. C 2009, 113, 1340913415.

http://dx.doi.org./10.1021/jp808536v

16. Zhang, X.-H.; Cui, Y.; Katoh, R.; Koumura, N.; Hara K. J. Phys. Chem. C 2010, 114, 18283-18290. http://dx.doi.org./10.1021/jp105548u

17. Irgashev, R. A.; Karmatsky, A. A.; Kozyukhin, S. A.; Ivanov, V. K.; Sadovnikov, A.; Kozik, V. V.; Grinberg, V. A.; Emets, V. V.; Rusinov, G. L.; Charushin, V. N. Synth. Met. 2015, 199, 152-158.

http://dx.doi.org./10.1016/i.synthmet.2014.11.024

18. Liang, Y.; Peng, B.; Liang, J.; Tao, Z.; Chen, J. Org. Lett. 2010, 12, 1204-1207. http://dx.doi.org./10.1021/ol902973r

19. Nishida, J. I.; Masuko, T.; Cui, Y.; Hara, K.; Shibuya, H.; Ihara, M.; Hosoyama, T.; Goto, R.; Mori, S.; Yamashita, Y. J. Phys. Chem. C 2010, 114, 17920-17925.

http://dx.doi.org./10.1021/ip912047u

20. Irgashev, R. A.; Karmatsky, A. A.; Rusinov, G. L.; Charushin, V. N. Beilstein J. Org. Chem. 2015, 11, 10001007. http://dx.doi.org./10.3762/bjoc.11.112

21. Fuller, L. S.; Iddon, B.; Smith, K. A. J. Chem. Soc., Perkin Trans. 1 1997, 3465-3470. http://dx.doi.org./10.1039/A701877K

22. Nakayama, J.; Nakamura, Y.; Murabayashi, S.; Hoshino, M. Heterocycles 1987, 26, 939-942. http://dx.doi.org./10.3987/R-1987-04-0939

23. Shi, J.; Chen, J. N.; Chai, Z. F.; Wang, H.; Tang, R. L.; Fan, K.; Wu, M.; Han, H. W.; Qin, J. G.; Peng, T. Y.; Li, Q. Q.; Li, Z. J. Mater. Chem. 2012, 22, 18830-18838.

http://dx.doi.org./10.1039/C2JM33833E

24. Hua, Y.; Chang, S.; Wang, H. D.; Huang, D. D.; Zhao, J. Z.; Chen, T.; Wong, W. Y.; Wong, W. K.; Zhu, X. J. J. Power Sources 2013, 243, 253-259.

http://dx.doi.org./10.1016/i.jpowsour.2013.05.157

25. Hua, Y.; Chang, S.; He, J.; Zhang, C.; Zhao, J.; Chen, T.; Wong, W.-Y.; Wong, W.-K.; Zhu, X. Chem. -Eur. J. 2014, 20, 6300-6308. 
http://dx.doi.org./10.1002/chem.201304897

26. Sorohhov, G.; Yi, C.; Grätzel, M.; Decurtins, S.; Liu, S.-X. Beilstein J. Org. Chem. 2015, 11, 1052-1059. http://dx.doi.org./10.3762/bjoc.11.118

27. Mishra, A.; Fischer, M.; Bäuerle, P. Angew. Chem. Int. Ed. 2009, 48, 2474-2499. http://dx.doi.org./10.1002/anie.200804709

28. Clifford, J. N.; Martinez-Ferrero, E.; Viterisi, A.; Palomares, E. Chem. Soc. Rev. 2011, 40, 1635-1646. http://dx.doi.org./10.1039/B920664G

29. Zhang, S.; Yang, X.; Numata, Y.; Han, L. Energy Environ. Sci. 2013, 6, 1443-1464. http://dx.doi.org./10.1039/C3EE24453A 